日本基礎心理学会大会で行われたシンポジウムをもとにした本特集 “人間工学と心理学 一応用と基礎一”も，ょうやくにして結論にまでたどりついた。シンポジウムそのものは 3 時間半で，あっという間に終わってしまったが，シンポジウム開催までの先生方との交 渉, 大会終了後の編集委員会におけるつめ, それに先生方への原稿執筆の交渉, 予定期限 が過ぎてからの原稿の催促など，手間どっている間に半年あまりが過ぎてしまった．その 間，執筆の諸先生方には無理な催促をさせていただいたてとでで迷惑をおかけしたと思う し，また，編集幹事の伊藤雅夫氏には先生方と筆者との間に立っていただいて，たいへん な心学をおかけしたのではないかと申しわけなく思っている．だが，てのようにして曲が りなりにも特集，それも筆者の専門とする人間工学と，出身学問である心理学とをつなぐ テーマでの特集が生まれようとしているてとは，ちょうど初めての子供をもつような喜び である．ての特集を読んで下さる方のなかから，ての境界領域に 1 人でも興味をもつ方が 生まれれば，私にとってたいへん幸せなととである.

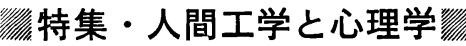

\section{6-1 まとめ}

第 1 編の序論から，順を追って企画者としての筆者の 言葉によってまとめてみよう。主旨説明は，シンポシウ ム当日に筆者が行ったものをもう 1 度述へており，てれ に賛同して下さった先生方の講演の題名が先ず記されて いる．当日の講演が，どのようなかたちに変更されて各 論文になっているのかが述へられている. 主な変更点 は，当日の討論者であられた丸山氏と難波氏にも，他の 演者同様，筆者が独断と偏見によって決めたテーマに関 して書いていただいたてとにある.てんなわけで，最終 的にはほとんど全部の先生方が筆者がお願いしたとおり のテーマで論文を書いて下さった（長町氏は，筆者がお 願いしたテーマ“情緒工学”に対し “情緒工学とその応 用”という軽微な変更を加えられたし, 野呂氏も最初の テーマ “官能検査と人間工学” から “一次元尺度構成と 人間のモデル”と変更された).

“応用と基礎についででは，丸山氏が筆者の設定し た基本テーマである “応用と基礎”という問題を真正面 から取り上げ, 格調高く問題の本質に迫って下さってい る. 3 つの問題をめぐって論を展開されている. 第一の “応用と基礎”がどう違うかという，いわば定義の問題 に関しては, 少なくとも人間工学と心理学の境界領域で は, 基礎的方法の応用問題への適用という方向よりも,
$<$ Special issue $>$ Summary, by Eitaro MASUYAMA.

\title{
増山英太郎
}

実際問題には実際問題なりのデー夕を新たに求め, それ らの蓄積のうえに独自の体系化をはかるという方向のほ うが強いと述へておられる. 第二の応用 (人間工学) と 基礎との関係については, “人間工学は基礎に熱いまな ざしを向けるが，基礎はおおむね知らん顔”と，面白い 表現をされている. 第三の人間工学者への要望と基礎心 理学者への要望の問題に関しては, 人間工学者へは “実 際問題をその解決だけにとどめずに，基礎・一般領域に 回帰ないしは深化・進入させようとする意識をもち続け てほしい”と要望をだされているが，一方の基碟心理学 者に対しては“応用からの働きかけがないかぎり，自己 のテーマに没頭してよいのではないか”と, 突き放した 見方をされており，興味深い。

第 2 編は “事故問題”であるが, “応用と基礎”とに かかわる現代社会がかかえる大きな問題である。“事故 防止の心理学”では, 增山は事故が詋りがもとで生ずる ものとしてとらえており, 感覚器に生ずる認知の誤り, 中枢に生ずる判断の誤り, 効果器に生ずる行動の誤り, 最後に, 誤った結果の処置のわるさがどのように事故に 結びつくかについて概説している.

“人間工学の立場からみた事故”においては，林氏は 最近の化学装置工業では, 計算機制御や計算機支援シス 
テム（ディジタル計装システム）が盛んに取り入れられ るようになったが，てれがもつ人間工学的諸問題をアン ケート調查結果をもとにして述べておられる. 全体を 3 つ, すなわちソフトアーゴノミッス上の問題点, マンー マシンインターフェイスの将来性, 運転・操作上の運転 貝の問題点とに分けて，興味深い多くの知見を述へてお られる。

“文明史の立場からみた事故”においては，広瀬氏は 全体を 3 つの章に分けて論を進めておられる. マシンシ ステムの高度化と世界の多椂性では, リスクマネージメ ントの考えが述べられ，チェルノブイリ原発事故のショ ックによって, 世界各国は安全基準の一元化を求める気 持が強いが，リスクの低減には当然のととながらコスト がかかり，国によってテクノロジーレベルの状況とコス 卜增に耐えられる経済水準とに違いがあるため，安全基 準は国によって多样なものとなるとしている。ヒューマ ンェラーを考えるでは，産業革命当時の事故は，本当は マシン自体の不具合によるものであっても，人間のせい にされることがほとんどであり，そのてとの根底には， もしマシンの過誤を珰めるとすると西欧機械文明が敗北 してしまうのではないかという考えが横たわっていると いう，だが，今世紀になってからは，徐々に国や企業家 が事故の被災者の救済をはかるようになってきたし、、 シンシステムから不良部分が除去されだし，事故数もき わめてはっきりと減少するようになってきたという。こ のてとは，裏を返せば減少した事故のほとんどはマシン によるものであり，主犯はマシンだったということであ る. マンーマシンシステムによる事故発生のうち，マン が主犯になる場合やマシンの異常をマンが四収できない 場合よりは，マシンとマンがエラーを交換していく間に エラーが増殖して事故となる場合のほうが，現代の巨大 システム事故には多いとしており，興味深い。ヒューマ ンエラーのスケープゴート化においては, 現代の巨大シ ステムの体面を守るために，未完熟なシステムが内部に かかえている欠陷をヒューマンシステムに転嫁しようと する最近の世の中の安易な傾向に対して警告を発してお られ，深い感銘を受けた。

第 3 編は “官能検查問題”であるが，“心理学の立場 よりみた官能検査”においては，筆者が先ず心理学的尺 度の 4 段階の別について述べ, 現在の心理学的尺度構成 法には多くのものがあるが，それでれがどのような性質 のものであって，相互にどんな関連性があるかについ て，十分には明らかでないてとの問題性を指摘してい る. 次いでフェヒナー法則とべキ関数という2つの精神 物理学を，Ekman に従って統合してみせている. 彼に
よる前者から後者の導出が人間工学の基礎知識になって もよいように思える. Luce 論文の意義では, 比率尺度, 間隔尺度, 対数間隔尺度を独立変数 $\mathrm{x}$ 之従属変数 $\mathrm{u}(\mathrm{x})$ とがとるときに，どのような式が可能かを数学的に求め た Luce 理論の重要性について説いており, 最近のノン メトリック MDS の安易な適用に対して注意を促して いる．尺度間の関係と尺度の 4 段階では， Luce 論文の あげている基準に照らして，心理学的尺度間の関係はど のようであるはずかを論じており，いくつかの今後に残 された問題があることを指摘している. 結びにかえてで は, 前述の未解決の問題に関しては悩みが深いが, 明る い見通しもないわけではなく，そのひとつは印東氏が 2 種の尺度間のきわめて美しい関係を得ておられるてとで あると結んでいる。

野呂氏による “一次元尺度構成と人間のモデル”で は, “心理学の立場よりみた官能検査”がいわば 1 次元 尺度構成の理論編とすれば，その実際への適用が述べら れている．先ずウレタンフォームを刺激材料としたかた さの 1 次元尺度構成の例が示され, 次いで評洒次元をど の上うなものにするか，何次元にするかは解析者にゆだ ねられているとしている. 続いてべクター法といわれる 多次元尺度構成法の一手法を用いて 8 個の表面あらさ試 料を 7 人の測定者に評定させた結果を解析し, 測定者に より試料の見方が違うてとを示しており，興味深い. 次 は人間のモデルと一次元尺度という題名のかなり難解な 内容ではあるが，人間というものは多次元の可能な次元 のなかで，それぞれ自分に適した 1 次元の判断を行うも のであると述へられているようである.

第 4 編では “情緒問題”が扱われている. “情緒の心 理学”に扔いては, 筆者が, 人間の表情からその情動が どの程度解読できるものかという古くからなされてきた 感情心理学の歴史をおおよそ述べ，次いで筆者自身の実 験結果を述へている．すなわち，日本舞踊の代表的演目 を中堅現役舞踊家によって 32 個の情緒語により SD 評 価をしてもらい，その結果に主成分分析法をほどてすと いうものである. 分析の結果, (1) 悲しみ, (2) 怒り, (3) 期待, (4) 驚き，(5) 容認，(6) 嫌悪，(7) 喜びの 7 つの因 子が得られ，そのうち最大の寄与率のものは “悲しみ” 因子 (20.7\%) であり，てれは悲しみ感情の表現を最も 重視するという従来から日本芸能にある伝統的考元と一 致するものである．次に，いわゆる上からの決定論的な 感情研究をも行ったので, てれを梅原氏の感情記号論の 修正というかたちで述へて，章を終えている。

“情緒工学とその応用”では長町氏がその定義を述べ ている. 研究者や時代によって種々の定義があろうが, 
情緒工学とは “人間を取り巻く物理的要因と人間の感情 や情緒といった心理的要因を結びつけ尺度化する分野で ある”と定義しておられる。情緒工学の研究の流れとし て, 氏が色彩空間の情緒的効果についての実験法の改良 を重ね，結局のとてろ現在のスライド方式に到達するま での苦労談が記されている．室内インテリアの物理的要 素（明度, 彩度, 色相）と心理的情緒との関係を尺度化 し，インテリアデザインに活用するてとを目指して， HLS と名づけて商品化されたという．さらに情緒工学 の研究方法とその応用例として, 室内インテリアの情緒 を研究するための方法についてまとめている．建築雑誌 に揭載されている SD 法に適した用語対を選択するの だが，500 対語を用意し，因子分析の結果，各因子の 意 味構造を残しながら相関係数の高い形容詞のなかからい くつかを抜くというようなやり方によって，最終的には HULIS では 227 語対にしたという. 次に，林の数量化 理論 I 類あるいはII類を用い，従属変数を形容詞，たと えば明るい部屋としたときに，独立変数としてどのよう なデザイン要素がどの程度きくかを調べる，室内面積， 天井高, 空の面積などの值をカテゴり一民度化して, 独 立変数のデータとして入力し, 数量化理論に従って解く という。もちろん，実験は前述のような部屋のカラース ライド（上のデザイン要素の組み合わせに従ってっくら れた部屋の）を 1 枚ずつ呈示しては，明るさという心理 的評価をさせるというものであろう．そのほか応用例に ついても述べられている，HULIS という長町氏らの開 発したソフトウェアで, 前述の HLS の拡張版の開発と 構成について述べている。構成のみについてまとめると システムの全体は，(1) 形容詞処理部，(2) イメージ処理 部, (3) グラフィック処理部の 3 つからなり，(1)で顧客 の話す形容詞がどのようなものであるかを理解し，その 結果から(2)では具体的なデザイン要素に変換して映像を 決定し，(3)ではそれに基づいて絵と色彩とをブラウン管 上に表示する．顧客とインテリアデザイナーは HULIS を間にして互いのイメージの交流を行い，最終的には顧 客が満足する住宅デザインを決定できるという，最後 に, “心理学がより機械化されつつあるなかで，人間工 学は（感情を含める方向で）より人間化へ進まねばなら ない性格をもつ”という，極めて示唆的な性格づけがな されているが，筆者としてはよりいっそう人間的人間工 学となるてとを願っている.

第 5 編は “騒音問題”であるが，先ず筆者が “騒音が 情楮に及ぼす問題”之題して述べている，最近の騒音に 関する住民のクレームは, 騒音そのものの大きさょり はむしろ情緒的な影響によるという意見をふまえて，
筆者が行った実験的研究の結果が内容となっている.ブ レーンストーミングによって思いつくかきりりの情緒語 27 対を SD 法の用語対として用意しておき。 24 種類の 騒音を 2 群（敏感群と鈍感群）に5 段階評価させ, 結果 を主成分分析した，その結果，第 1 亿怒り因子，第 2 に 悲しみ因子が抽出され，そこまでの累積寄与率は 90.7 \%であった。 因子得点を求めてみた結果, 打およそ騒音 敏感群は怒っているのに対し, 鈍感群は悲しんでいると なった。

次いで難波氏が “騒音問題の基礎から応用まで”と題 して述へておられるが, 騒音問題の基礎は音の精神物理 学であり, そのうえに応用研究があるとし, 基礎として の精神物理学的研究について述へておられる. Stevens の複雑な周波数成分をもった音の大きさを簡単に算出で きる Mark VIの計算法が紹介され，その実用性を種々 の音を用いて確かめておられ, 貴重である.さうに応用 的な実験という題名で, 最初に種々の衝撃音の評価方法 について論じられている．研究者間で必ずしも一致した 結果が得られていないようで, 問題の難しさを感ずる. 聴力保護具の性能についても実証的研究がなされている ようで, 成果もあがっているようである、社会調査にお いては，日本国内での居住地域の違い，国の違いによる 騒音の受けとめ方の違いが述へられ，川崎市において は, 有意味な音の発生については時間制限, 無意味な音 に対しては音量制限という指導要領が発表されているこ とは興味深い。紛争の調停・裁判をめぐってでは, 騒音 問題の調停, 裁判の際にも, 今やアンケート調查や心理 検查や閥値測定などの結果が, 状況によっては用いられ 始めているということが述べられ，心理技術が市民権を 得始めたひとつの証拠ともいえよう。最後のまとめで は, 騒音問題の解決には国内外の協力だけではなく, 学 際的な研究体制を組むととが急務であると結んでおられ るが，ての点関しては筆者も全く同感である.

各編のまとめは以上のとおりであるが，てれらは互い にどのようにからみ合っているのかを眺めてみるてとも 無䭾ではないだろう．事故というものは，ヒューマンエ ラーを発端とするてとが多い。広瀬氏も述べているよう に, マンーマシンシステムのマシンの部分が発達し，ほ とんどェラーを生じなくなってきたてとによる.てれは 工場の自動化のおかげである.この自動化の波は，今や 官能検査の現場にも押し寄せている，検查員の代わりに ロボットが, 感覚器官の代わりにセンサーが, 疲れを知 らずに働いている．官能検查のうち刺激強度の検出の仕 事は早晚，そのほとんどをセンサーが行うようになるだ ろう.すると,残るは好みの官能検査となるが, との部分 
はまだ当分ロボットでは無理だろう。だが，技術の進歩 は速いので，そう遠くない将来には一部の好みの検査に ロボットが割り込んでくるだろう。このようなロボット の実現には，長町氏が述べられている AI，つまり人工 知能の研究が進められる必要があろう。商品の好みとい う官能量が, 物理量からどのような関数に従って決定さ れるかを好みの集団別に決定し，そのアルゴリズムに従 ってロボットが検査を行ってくれればよいと思う。

また，事故は情緒とも大きな関係がある．機械の操作 を仮に間違えたとしても，冷静であればその 1 つのヒュ ーマンエラーが直ちに事故につながることはあまりない であろう。しかし，そてでたいていは“取り返しのつか ないととをしてしまった”というととで冷静さを失な う.すると，その場への適応ができなくなり，事故につ ながってしまうであろう，適量の情緒は，その人を人間 らしくみせるが，過度になると思考力をにぶらせるの で, 注意が肝要である.

とてろで, HULIS のとてろで長町氏は顧客のイメー ジに合わせてデザイン要素を組み合わせる旨を述へてお られるが，てれはまさに官能検査の問題，極めて進んだ 官能検查の問題といえよう．最近の官能検査の動向をみ ると，官能検查というょりは官能評価とよぶにふさわし い. 商品の物理的特性よりは，それがもつイメージの方 向に各メーカーが重点を移してきているように思えるか らである. 最後に, 難波氏の精神物理学的研究は, これ
も 完全に 官能検査の 中心的問題 であるが，同氏の述へ られる騒音問題の調停, 裁判となると, 事故が生じてし まってからの法律問題のなかに含まれる問題ともいえよ う. また，騒音は悪い音の官能検查の問題であるととら えるとともできよう. 現在の官能検查研究会は, 主とし て良い音を発する音響機器の官能評価のみしか対象にし ていないが，学問としては騒音も対象にすべきであろ う．騒音に次ぐ住民からのクレームは悪臭公害である が，香水の官能評価は，同じょうな意味からこの悪臭を も対象にすべきように思う。

さて，ここで特集の標題を思いだそう。それは，“人 間工学と心理学一応用と基礎—”というものであった. 副題に関しては丸山氏が十分論じて下さったので, 標題 と論文の構成との関係を最後に述へてて終わるととにしよ う.気つかれた読者もあるかと思うが，すべての編で， 筆者が標題のうちの心理学の側からみる役割を演じてい るのである．その結果，他の執筆者にはほとんどすべて 人間工学の側からみていただくてとになってしまった （広瀬氏のみには文明史という中間の立場に立っていた だいた)。これは何となくそうなってしまったのだが， 今から考えると, 筆者が出身である心理学の読者に, こ の領域をなんとか案内してみたいという無意識の意図が 働いていたのかもしれない，永々と述へてきたが，よう やく半年間, 胸に重くのしかかっていたものも吐きだせ たようなので，ててで本当に筆を置くことにする. 